\title{
Okul Öncesi Öğretmeni Adayları İle Sınıf Öğretmeni Adaylarının İnformal Öğrenme Şekillerinin İncelenmesi ${ }^{a}$
}

\author{
Murat Bartanº, Serap Akbaba Dağc, Handan Kılıç Şahinn', Sevinç Demir Kaya ${ }^{\mathrm{e}}$
}

\section{Özet}

$\mathrm{Bu}$ araştırma okul öncesi öğretmen adayları ile sınıf öğretmeni adaylarının informal öğrenme davranışlarının belirlenmesi amacıyla gerçekleştirilmiştir. Araştırma, betimsel tarama modelindedir. Araştırma, 2018-2019 eğitim öğretim yılında Kütahya Dumlupınar Üniversitesi eğitim fakültesinde okuyan 289 okul öncesi öğretmeni adayı ile 230 sınıf öğretmeni adayı toplam 519 öğretmen adayının katılımı ile gerçekleşmiştir. Araştırmada veri toplama aracı olarak İnformal Öğrenme Anketi kullanılmıştır. Verilerin analizinde betimsel istatistiklerden yararlanılmıştır. Araştırma sonuçlarına göre öğretmen adayları informal öğrenme etkinliklerinde en sık internetten arama yapmayı, en az ise alanları ile ilgili dergileri incelemeyi belirtmişlerdir. Öğretmen adayları informal öğrenmelerini etkileyen çevresel engelleyicilere en fazla zaman eksikliğini, en az ise parasal ödüllerin olmamasını ifade etmişlerdir. İnformal öğrenmelerini etkileyen kişisel özelliklerine bakıldığında ise okul öncesi öğretmen adayları en fazla öğrenme arzusunu, sınıf öğretmeni adayları ise en fazla mesleki alana ilgiyi belirtirken en az etki eden kişisel özellik olarak da mesleki becerilere ilişkin algılarını ifade etmişlerdir.
Anahtar Kelimeler

İnformal öğrenme

Okul öncesi eğitim Sınıf eğitimi

Öğretmen adayı

Makale Hakkında

Geliş Tarihi: 23.07.2019

Kabul Tarihi: 04.05.2020

Doi: 10.18026/cbayarsos.595405

\section{Investigation of Informal Learning Patterns of Prospective Pre Preschool Teachers and Prospective Primary School Teachers}

\section{Abstract}

This research was carried out to determine the informal learning behaviors of prospective pre preschool teachers and prospective primary school teachers. The research is a descriptive survey model. The research was conducted in the 2018-2019 academic year with the participation of a total of 519 teachers of 289 prospective preschool teachers and 230 prospective primary school teachers who were attending at Kütahya Dumlupınar University Faculty of Education. Descriptive statistics were used to analyze the data. According to the results of the research, prospective teachers stated that they search the internet most frequently and at least examine journals related to their fields in informal learning activities. They stated that the most lack of the time and at least the lack of least the monetary rewards for environmental inhibitors affecting informal learning activities. When the personal characteristics that affect informal learning are examined, prospective preschool teachers stated their desire to learn the most, while the prospective primary school teachers expressed the most interest in the professional field and their perceptions about professional skills as the least effective personality characteristic.
Keywords

Informal learning

Preschool education

Primary education

Pre-service Teachers

About Article

Received: 23.07.2019

Accepted: 04.05.2020

Doi: 10.18026/cbayarsos.595405

\footnotetext{
a Bu çalışma, Uluslararası Bilim ve Eğitim Kongresi 2019 (UBEK2019) sözlü bildiri olarak sunulmuştur.

b İletişim Yazarı: murat.bartan@dpu.edu.tr. Dr. Öğr. Üyesi, Kütahya Dumlupınar Üniversitesi Eğitim Fakültesi. Orcıd: 0000-0003-2947-5643

c Dr. Öğr. Üyesi, Kütahya Dumlupınar Üniversitesi Eğitim Fakültesi. Orcıd: 0000-0003-2188-563X

d Arș. Gör, Kütahya Dumlupınar Üniversitesi Eğitim Fakültesi. Orcıd: 0000-0002-1917-0937

e Arş. Gör, Kütahya Dumlupınar Üniversitesi Eğitim Fakültesi. Orcıd: 0000-0002-2210-0235
} 


\section{Giriş}

Milli Eğitim Bakanlığı 2023 eğitim vizyonunda hayat boyu öğrenme için, mesleki, sosyal ve kültürel becerilere yönelik hayat boyu öğrenme programları güncellenerek çeşitlendirileceğini, hayat boyu öğrenme süreçlerine yönelik toplumsal farkındalığa ilişkin çalışmalar yapılacağını ifade etmiş ve özellikle hayat boyu öğrenme faaliyetlerine dikkat çekmiştir (Meb, 2018). Hayat boyu eğitimin temel felsefesi eğitimin bir yaşam biçimi haline gelmesidir. Öğrenmenin yaşının olmayacağı ve bireyin örgün eğitimle kısıtlanmayacağ ifade edilmektedir. Ancak öğrenme planlı, programlı kasıtlı veya kasıtlı olmayan tüm etkinlikleri kapsadığı için hayat boyu eğitim kavramı yerini hayat boyu öğrenme kavramına bırakmıştır (Kaya, 2016). Nitekim Hayat boyu öğrenme; “yaşamın başından sonuna kadar süren, kişisel, toplumsal, sosyal veya iş yaşamını içine alan, bilgi, beceri ve yetilerin geliştirilmesi amacıyla yapılan, ister örgün ister yaygın, sürekli devam eden, bütün amaçlı öğrenme etkinliklerini kapsayan bireysel ve kurumsal öğrenmeyi içeren belirli bir süreyle yapılan eğitim faaliyetlerinin tümü" şeklinde tanımlamaktadır (Güleç, Çelik ve Demirhan, 2012).

Eğitim öğretim faaliyetlerini hayat boyu öğrenmeye dönüştüren özelliklerin başında ise informal öğrenme gelmektedir (Göğebakan Yıldız 2017). Günümüzde eğitim ile ilgili yeniliklerin merkezine informal öğrenme konulmaktadır (Garrick, 2001). İnformal öğrenme, bir örgün eğitim programı gibi yapılandırılmamış (Rogers,2014) insanların yeni şeyleri keşfetmesi ve tecrübelerini artırması (Bozdoğan 2007) ve günlük hayatlarında karşılaşabilecekleri problemlere çözüm getirebilme yetisi kazanmalarını amaçlayan (Türkmen, 2010), okulda veya sınıf dışında meydana gelen öğrenmeler şeklinde tanımlanmaktadır (Kara, 2010). Lohman ( 2005 ) informal öğrenmeyi; Başkalarıyla konuşma ve onlarla işbirliği yapma, materyal ve kaynak paylaşma, başkalarını gözlemleme veya onların davranışlarını yansıtma, internette arama yapma, dergileri tarama ve kendi kendine deneme yanılma yolu ile öğrenme olarak tanımlamıştır.

İnformal öğrenme etkinlikleri, okulda gerçekleştirilen öğrenme aktivitelerini güçlendirmek, daha eğlenceli hale getirmek ve en önemlisi etkili, kalıcı öğrenmeler sağlamak için yürütülmektedir (Lakin, 2006). Eshach (2007) okul dışı öğrenme ortamlarının öğrencilerin ilgi ve motivasyonlarını arttırdığını ve bu sayede öğrenmeye istekli olmalarını sağladığı ifade etmektedir. Araştırmalar sonucunda, okullarda kazandırmayı amaçladığımız becerilerin okul dışı informal ortamlarda çocuklar tarafından daha hızlı öğrenildiği (Hofstein ve Rosenfeld, 1996; Melber ve Brown, 2008; Keskin ve Kaplan 2012; Lakin, 2006; Stocklmayer, Rennie ve Gilbert, 2010; Wulf, Mayhew ve Finkelstein, 2010), öğrencilerin akademik başarılarının artmasında informal öğrenme ortamlarının önemli bir fonksiyonu olduğu görülmektedir (Yavuz ve Balkan Kıyıc1, 2012).

Eraut (2004) informal öğrenmenin öğrenenlere örgün ortamlardan daha fazla özgürlük ve esneklik sunduğunu, Moore ve Klein, (2020) informal öğreme etkinliklerinin öğrenmeyi kolaylaştırdığını ifade etmişlerdir. Yapılan araştırmalar informal öğrenmenin, bireylerin öğrenme etkinliğindeki rolünün ve etkisinin liseden itibaren daha önemli hale geldiğini yetişkinlerin \%90'nından fazlasının informal öğrenme etkinlikleri içinde yer aldığını ve tüm yetişkinler arasında informal öğrenme etkinliklerine ayrılan zamanın son bir yıl içinde haftalık 15 saate çıktığını belirtmektedir (Livingstone, 2002: Akt; Alakurt, 2015). 
Rogers (2013) göre öğretmen yetiştirme sürecinde de formal eğitimin yanında informal öğrenme etkinliklerinede yer verilmelidir. Çünkü öğretmen adaylarının mesleklerini uygulayacakları ortamlarda informal eğitim çalışmalarına yer vermek zorunda kalacaklarını ifade etmektedir. Nitekim bir alanda uzmanlaşmış öğretmen gruplarının, kendilerine özgü öğrenme davranışlarının olduğuda bilinmektedir (Alakurt, Öztürk, Karademir ve Yılmaz (2019). Özellikle temel eğitim sürecinde görev alacak öğretmenlerin informal öğrenme ortamlarını daha etkili kullanması gerekmektedir. Bu bağlamda hem alan yazın hem de araştırmaların sonuçları dikkate alındığında öğretmen adaylarının informal öğrenme yolları ile okul dışı öğrenme ortamlarına başvurdukları düşünülmektedir.

Alan yazın incelendiğinde okul öncesi öğretmeni adayları ile sınıf öğretmeni adaylarının informal öğrenme şekilleri ile ilgili herhangi bir çalışmaya rastlanmamıştır. Bu açıdan bu araştırmanın alan yazınına katkı getireceği beklenmektedir. Bu bakımdan araştırma Okul Öncesi Öğretmeni Adayları İle Sınıf Öğretmeni Adaylarının okul dışı informal öğrenme davranışlarının belirlenmesi amacı ile gerçekleştirilmiştir. Bu amaçla aşağıdaki sorulara yanıt aranmıştır:

1. Okul öncesi öğretmeni adayları ile sınıf öğretmeni adaylarının okul dışı hangi informal öğrenme etkinliklerinde bulunmaktadır?

2. Okul öncesi öğretmeni adayları ile sınıf öğretmeni adaylarının informal öğrenme etkinliklerinde bulunmalarını etkileyen çevresel engelleyiciler nelerdir?

3. Okul öncesi öğretmeni adayları ile sınıf öğretmeni adaylarının informal öğrenme etkinliklerinde bulunmalarını etkileyen kişisel özellikler nelerdir?.

\section{Yöntem}

\section{Araştırma Modeli}

$\mathrm{Bu}$ araştırma okul öncesi öğretmen adayları ile sınıf öğretmeni adaylarının informal öğrenme davranışlarının belirlenmesi amacıyla gerçekleşmiştir. Bu nedenle araştırma, betimsel tarama modelindedir. Tarama modeli geçmişte ya da hali hazırda var olan bir durumu olduğu biçimiyle betimlemeyi amaçlayan ve araştırmaya konu olan, birey veya nesneyi, kendi koşulları içerisinde olduğu gibi tanımlamaya çalışan araştırma modelidir (Karasar, 2012)..

\section{Evren ve Örneklem / Çalışma Grubu / Katılımcılar}

Araştırma, 2018-2019 eğitim öğretim yılında Kütahya Dumlupınar Üniversitesi eğitim fakültesinde okuyan 289 okul öncesi öğretmeni adayı ile 230 sınıf öğretmeni adayı toplam 519 öğretmen adayının katılımı ile gerçekleşmiştir. Öğretmen adaylarına ilişkin kişisel bilgiler Tablo 1'de sunulmuştur.

Tablo1. Araştırmaya katılan öğretmen adaylarına ilişkin bilgiler

\begin{tabular}{lcccccc} 
& \multicolumn{2}{c}{$\begin{array}{c}\text { Okul öncesi öğretmeni } \\
\text { adayları }\end{array}$} & \multicolumn{2}{c}{$\begin{array}{c}\text { Sinıf öğretmeni } \\
\text { adayları }\end{array}$} & \multicolumn{2}{c}{ Toplam } \\
\hline Cinsiyet & $\mathbf{N}$ & $\mathbf{\%}$ & $\mathbf{N}$ & $\mathbf{\%}$ & $\mathbf{N}$ & $\mathbf{\%}$ \\
\hline Kadın & 252 & 87,2 & 188 & 81,7 & 440 & 84.77 \\
Erkek & 37 & 12,8 & 42 & 18,3 & 79 & 15.23
\end{tabular}




\begin{tabular}{lcccccc} 
Toplam & 289 & 100 & 230 & 100 & 519 & 100 \\
\hline Sinif & $\mathbf{N}$ & $\mathbf{\%}$ & $\mathbf{N}$ & $\mathbf{\%}$ & $\mathbf{N}$ & $\mathbf{\%}$ \\
\hline 1.sinif & 90 & 31,1 & 40 & 17,4 & 130 & 25.05 \\
2. sinif & 77 & 26,6 & 54 & 23,5 & 131 & 25.24 \\
3.sinif & 55 & 19,1 & 73 & 31,7 & 128 & 24.66 \\
4.sinif & 67 & 23,2 & 63 & 27,4 & 130 & 25.05 \\
Toplam & 289 & 100 & 230 & 100 & 519 & 100 \\
\hline
\end{tabular}

Tablo 1 de araştırmaya katılan okul öncesi öğretmen adayları ile sınıf öğretmeni adaylarının cinsiyet ve sınıf düzeylerine ilişkin bilgileri verilmiştir. Tablo incelendiğinde araştırmaya katılan okul öncesi öğretmen adaylarının \%87.2'si kadın (n=252), \%12.8'i erkek (n=37) öğretmen adaylarından oluşmaktadır. Okul öncesi öğretmen adaylarının \%31.1'i birinci sınıf ( $n=90), \% 26.6$ 'sı ikinci sınıf ( $n=77), \% 19.1$ 'i üçüncü sınıf $(n=55)$ ve \%23.2'si dördüncü sınıf $(\mathrm{n}=67)$ öğretmen adaylarından oluşmaktadır. Tablo incelendiğinde araştırmaya katılan sınıf öğretmeni adaylarının \%81.7'si kadın ( $n=188)$, \%18.3'ü erkek (n=79) öğretmen adaylarından oluşmaktadır. sınıf öğretmeni adaylarının \%17.4'ü birinci sınıf $(n=40), \% 25.5$ 'i ikinci sınıf (n=54), \%31.7'si üçüncü sınıf ( $n=73)$ ve \%27.4'ü dördüncü sınıf $(n=63)$ öğretmen adaylarından oluşmaktadır. Tablo incelendiğinde araştırmaya katılan toplam öğretmen adaylarının \%84.77'si kadın ( $\mathrm{n}=440), \% 15.23$ '̈̈ erkek $(\mathrm{n}=79)$ öğretmen adaylarından oluşmaktadır. Öğretmen adaylarının \%25.05'i birinci sınıf ( $n=130)$, \%25.24' ü ikinci sınıf ( $n=131), \% 24.66$ 's üçüncü sınıf ( $n=128)$ ve \%25.05'i dördüncü sınıf ( $n=130)$ düzeyindeki öğretmen adaylarından oluşmaktadır.

\section{Veri Toplama Araçları}

Araştırmada veri toplama aracı olarak öğretmen adaylarının kişisel bilgilerini belirlemek için kişisel bilgi formu ile Lohman (2005) tarafından geliştirilen ve Alakurt (2015) tarafından Türkçeye uyarlanan “Informal Öğrenme Anketi - Informal Learning Survey” kullanılmıştır. Anketin Türkçeye uyarlaması çalışmasında hazırlanan taslak form Eğitim Programları ve Ölçme ve Değerlendirme alanında uzmanların görüşüne sunulmuştur. Uzmanlardan gelen dönüt ve düzeltmelerin ardından anket formunun pilot uygulaması yapılmıştır. Informal Öğrenme Anketi informal öğrenme etkinlikleri, informal öğrenmeyi etkileyen çevresel engelleyiciler ve kişisel özellikler olmak üzere üç bölümden oluşmaktadır. Cevaplar için "1Hiçbir zaman" ve "5-Her zaman" biçiminde 5’li derecelendirme kullanılmıştır. Araştırma öğretmen adayları ile birlikte yürütüldüğü için ölçek maddesinde belirtilen "iş arkadaşı" ifadesi öğretmen adaylarına "sınıf arkadaşı" şeklinde değiştirilerek sorulmuştur.

\section{Verilerin Toplanması ve Analizi}

Araştırmada veriler, Informal Öğrenme Anketi'nin öğretmen adaylarına yüz yüze uygulanması sonucunda toplanmıştır. Çalışma betimsel bir araştırmadır ve verilerin analizinde betimsel istatistiklerden yararlanılmıştır. 


\section{Bulgular}

Okul öncesi ve sınıf öğretmeni adaylarının okul dışı gerçekleştirdikleri informal öğrenme etkinliklerine ilişkin bulgular aşağıda tablolar halinde verilmiştir.

Tablo 2. Okul Öncesi ve Sınıf Öğretmeni adaylarının Okul Dışı Gerçekleştirdikleri İnformal Öğrenme Etkinlikleri

\begin{tabular}{|c|c|c|c|c|c|c|c|}
\hline Informal Etkinlikler & Bölüm & $\mathbf{N}$ & Min & Mak & $\begin{array}{l}\text { Ort } \\
\bar{X}\end{array}$ & Mod & $\begin{array}{l}\text { Standart } \\
\text { Sapma }\end{array}$ \\
\hline \multirow{2}{*}{$\begin{array}{l}\text { Diğerleri (dostlarım, } \\
\text { arkadaşlarım, sınıf } \\
\text { arkadaşlarım vb.) ile } \\
\text { konuşurum }\end{array}$} & $\begin{array}{l}\text { Okul } \\
\text { Öncesi ÖA }\end{array}$ & 289 & 1.00 & 5.00 & 4,03 & 4 & .867 \\
\hline & Sinıf ÖA & 230 & 1.00 & 5.00 & 4,02 & 4 & 801 \\
\hline \multirow{2}{*}{$\begin{array}{l}\text { Diğerleri (dostlarım, } \\
\text { arkadaşlarım, sınıf } \\
\text { arkadaşlarım vb.) ile } \\
\text { işbirliği yaparım }\end{array}$} & $\begin{array}{l}\text { Okul } \\
\text { Öncesi ÖA }\end{array}$ & 289 & 1.00 & 5.00 & 3,72 & 4 & .920 \\
\hline & Sınıf ÖA & 230 & 1.00 & 5.00 & 3,63 & 3 & ,933 \\
\hline \multirow{2}{*}{$\begin{array}{l}\text { Diğerlerini (dostlarım, } \\
\text { arkadaşlarım, sınıf } \\
\text { arkadaşlarım vb.) } \\
\text { gözlemlerim }\end{array}$} & $\begin{array}{l}\text { Okul } \\
\text { Öncesi ÖA }\end{array}$ & 289 & 1.00 & 5.00 & 3,73 & 4 & .970 \\
\hline & Sinıf ÖA & 230 & 1.00 & 5.00 & 3,55 & 4 & 1,084 \\
\hline \multirow{2}{*}{$\begin{array}{l}\text { Diğerleri (dostlarım, } \\
\text { arkadaşlarım, sınıf } \\
\text { arkadaşlarım vb.) ile } \\
\text { materyal ve kaynak } \\
\text { paylaşırım }\end{array}$} & $\begin{array}{l}\text { Okul } \\
\text { Öncesi ÖA }\end{array}$ & 289 & 1.00 & 5.00 & 3,82 & 4 & .943 \\
\hline & Sinıf ÖA & 230 & 1.00 & 5.00 & 3,60 & 4 & 1,044 \\
\hline \multirow[t]{2}{*}{ İnternette arama yaparım } & $\begin{array}{l}\text { Okul } \\
\text { Öncesi ÖA }\end{array}$ & 289 & 1.00 & 5.00 & 4,33 & 5 & .874 \\
\hline & Sinıf ÖA & 230 & 1.00 & 5.00 & 4,65 & 5 & 661 \\
\hline \multirow[t]{2}{*}{$\begin{array}{l}\text { Mesleğimle/Alanımla ilgili } \\
\text { dergileri incelerim }\end{array}$} & $\begin{array}{l}\text { Okul } \\
\text { Öncesi ÖA }\end{array}$ & 289 & 1.00 & 5.00 & 3,08 & 3 & 1.201 \\
\hline & Sinif ÖA & 230 & 1.00 & 5.00 & 2,57 & 2 & 1,176 \\
\hline \multirow{2}{*}{$\begin{array}{l}\text { Deneme yanilma yoluyla, } \\
\text { kendi kendime yeni yollar } \\
\text { denerim }\end{array}$} & $\begin{array}{l}\text { Okul } \\
\text { Öncesi ÖA }\end{array}$ & 289 & 1.00 & 5.00 & 3,29 & 3 & 1.143 \\
\hline & Sinif ÖA & 230 & 1.00 & 5.00 & 3,27 & 3 & 1,072 \\
\hline \multirow[t]{2}{*}{$\begin{array}{l}\text { Kendi eylemlerim üzerinde } \\
\text { iyice düşünürüm }\end{array}$} & $\begin{array}{l}\text { Okul } \\
\text { Öncesi ÖA }\end{array}$ & 289 & 1.00 & 5.00 & 3,95 & 4 & 1.039 \\
\hline & Sinif ÖA & 230 & 1.00 & 5.00 & 4,09 & 5 & ,912 \\
\hline \multirow{2}{*}{$\begin{array}{l}\text { Üyesi olduğum çevrimiçi } \\
\text { topluluğa } \\
\text { sorarım/danışırım }\end{array}$} & $\begin{array}{l}\text { Okul } \\
\text { Öncesi ÖA }\end{array}$ & 289 & 1.00 & 5.00 & 3,16 & 4 & 1.223 \\
\hline & Sinıf ÖA & 230 & 1.00 & 5.00 & 2,97 & 3 & 1,315 \\
\hline
\end{tabular}

Tablo 2'de okul öncesi öğretmen adayları ile sınıf öğretmeni adaylarının okul dışı gerçekleştirdikleri informal öğrenme etkinliklerin ortalama puanlarına bakıldığında öğretmen adaylarının en sık başvurdukları informal öğrenme etkinliğinin "İnternette arama

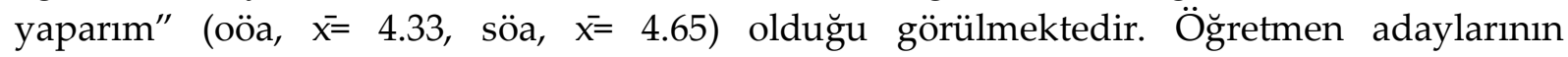
başvurdukları diğer informal öğrenme etkinlikleri ise okul öncesi öğretmen adayları için

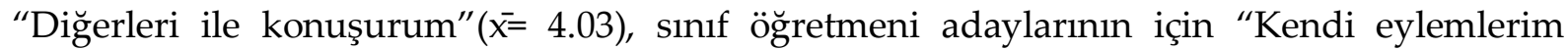
üzerinde iyice düşünürüm" $(\bar{x}=4.09)$ olduğu görülmektedir. Üçüncü sırada okul öncesi 
öğretmen adayları için "Kendi eylemlerim üzerinde iyice düşünürüm”( $\overline{x=3.95), ~ s i n ı f ~}$

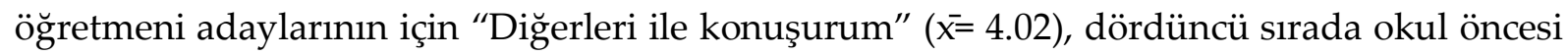
öğretmen adayları için "Diğerleri ile materyal ve kaynak paylaşırım" ( $\bar{x}=3.82)$, sınıf öğretmeni adaylarının için "Diğerleri ile işbirliği yaparım" $\left(x^{-}=3.63\right)$, beşinci sırada okul öncesi öğretmen adayları için “Diğerlerini gözlemlerim" ( $\bar{x}=3.73)$, sınıf öğretmeni adaylarının için “Diğerleri ile materyal ve kaynak paylaşırım" ( $\overline{x=3.60)}$, altıncı sırada okul öncesi öğretmen adayları için "Diğerleri ile işbirliği yaparım" $(\bar{x}=3.72)$, sınıf öğretmeni adaylarının için “Diğerlerini gözlemlerim" ( $\overline{x=3.55), ~ y e d i n c i ~ s ı r a d a ~ o k u l ~ o ̈ n c e s i ~ o ̈ g ̆ r e t m e n ~ v e ~ s i n ı f ~ o ̈ g ̆ r e t m e n i ~ a d a y l a r ı n ı n ~}$ için "Deneme yanılma yoluyla, kendi kendime yeni yollar denerim" (oöa, $\bar{x}=3.29$, söa, $\overline{\mathrm{x}}=3.27$ ), sekizinci sırada okul öncesi öğretmen ve sınıf öğretmeni adaylarının için "Üyesi olduğum çevrimiçi topluluğa sorarım/danışırım" (oöa, $\bar{x}=3.16$, söa, $\bar{x}=2.97$ ), şeklinde informal öğrenme etkinlikleri gerçekleştirdikleri görülmektedir. okul öncesi öğretmen ve sınıf öğretmeni adaylarının en az başvurdukları informal öğrenme etkinliğinin ise "Mesleğimle/Alanımla ilgili dergileri incelerim" (оöa, $\overline{x=3.08, ~ s o ̈ a, ~} \overline{x=2.57)}$ olduğu belirlenmiştir.

Tablo 3. Okul Öncesi ve Sınıf Öğretmeni adaylarının informal öğrenme etkinliklerinde bulunmalarını etkileyen çevresel engelleyiciler

\begin{tabular}{|c|c|c|c|c|c|c|c|}
\hline \multicolumn{2}{|l|}{ Çevresel Engelleyiciler } & $\mathbf{N}$ & Min & Mak & $\begin{array}{l}\text { Ort } \\
\bar{X}\end{array}$ & Mod & $\begin{array}{l}\text { Standart } \\
\text { Sapma }\end{array}$ \\
\hline \multirow{2}{*}{$\begin{array}{l}\text { Zaman } \\
\text { eksikliği/Zamanınınız } \\
\text { olmaması }\end{array}$} & $\begin{array}{c}\text { Okul } \\
\text { Öncesi ÖA }\end{array}$ & 289 & 13,00 & 43.00 & 28,97 & 28,00 & 6,048 \\
\hline & Sinıf ÖA & 230 & 13,00 & 42.00 & 27.26 & 25.00 & 5.592 \\
\hline \multirow{2}{*}{$\begin{array}{l}\text { Sınıf arkadaşlarınızın } \\
\text { ilgi alanlarına yakın } \\
\text { olmamanız }\end{array}$} & $\begin{array}{c}\text { Okul } \\
\text { Öncesi ÖA }\end{array}$ & 289 & 9.00 & 42.00 & 20.77 & 18.00 & 6,659 \\
\hline & Sinif ÖA & 230 & 9.00 & 43.00 & 24.00 & 26.00 & 6.732 \\
\hline \multirow{2}{*}{$\begin{array}{l}\text { Bilgi ve iletişim } \\
\text { teknolojilerine } \\
\text { erişiminizin } \\
\text { olmaması }\end{array}$} & $\begin{array}{c}\text { Okul } \\
\text { Öncesi ÖA }\end{array}$ & 289 & 9.00 & 44.00 & 25.24 & 28.00 & 6.984 \\
\hline & Sınıf ÖA & 230 & 9.00 & 45.00 & 26.65 & 26.00 & 6.567 \\
\hline \multirow[t]{2}{*}{$\begin{array}{l}\text { Parasal ödüllerin } \\
\text { olmaması }\end{array}$} & $\begin{array}{c}\text { Okul } \\
\text { Öncesi ÖA }\end{array}$ & 289 & 9.00 & 45.00 & 14.50 & 9.00 & 7.072 \\
\hline & Sinıf ÖA & 230 & 9.00 & 45.00 & 15.36 & 9.00 & 8.167 \\
\hline \multirow{2}{*}{$\begin{array}{l}\text { Sınıf arkadaşlarınızı } \\
\text { yeterince } \\
\text { tanımamanız }\end{array}$} & $\begin{array}{c}\text { Okul } \\
\text { Öncesi ÖA }\end{array}$ & 289 & 9.00 & 41.00 & 19.32 & 21.00 & 5.641 \\
\hline & Sinıf ÖA & 230 & 9.00 & 45.00 & 23.93 & 21.00 & 8.047 \\
\hline
\end{tabular}

Tablo 3 incelendiğinde okul öncesi öğretmen adayları ile sınıf öğretmeni adaylarının informal öğrenme etkinliklerinde bulunmalarını etkileyen çevresel engelleyicilerin toplam puanlarının ortalamalarına bakıldığında en fazla "Zaman eksikliği/Zamanınınız olmama"

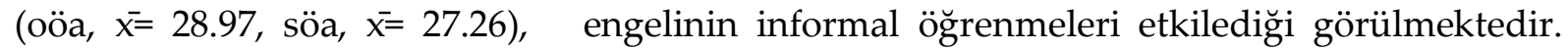

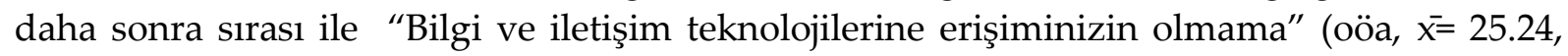
söa, $\overline{x=26.65)}$ ) , "Sınıf arkadaşlarınızın ilgi alanlarına yakın olmama" (oöa, $\overline{x=20.77, ~ s o ̈ a, ~} \overline{x=}$ 24.00), , "Sınıf arkadaşlarınızı yeterince tanımamanız" (oöa, $\bar{x}=19.32$, söa, $\bar{x}=23.93$ ), ve son olarak "Parasal ödüllerin olmama" (oöa, $\bar{x}=14.50$, söa, $\bar{x}=15.36$ ), çevresel engelleyicilerin okul öncesi öğretmen adayları ile sınıf öğretmeni adaylarının informal öğrenme etkinliklerinde bulunmalarını etkilediği görülmektedir. 
Tablo 4. Okul öncesi öğretmenlerinin informal öğrenme etkinliklerinde bulunmalarını etkileyen kişisel özellikler

\begin{tabular}{|c|c|c|c|c|c|c|c|}
\hline Kişisel Özellikler & & $\mathbf{N}$ & Min & Mak & $\begin{array}{l}\text { Ort } \\
\bar{X}\end{array}$ & Mod & $\begin{array}{l}\text { Standart } \\
\text { Sapma }\end{array}$ \\
\hline \multirow{2}{*}{$\begin{array}{l}\text { Bir etkinliğe } \\
\text { başlama ve devam } \\
\text { etme kararlılığınız }\end{array}$} & $\begin{array}{l}\text { Okul Öncesi } \\
\text { ÖA }\end{array}$ & 289 & 17.00 & 45.00 & 37.27 & 45.00 & 6.064 \\
\hline & Sınıf ÖA & 230 & 17.00 & 45.00 & 37.20 & 45.00 & 6.566 \\
\hline \multirow{2}{*}{$\begin{array}{l}\text { Mesleki } \\
\text { becerilerinize/yeten } \\
\text { eklerinize ilişkin } \\
\text { algınız }\end{array}$} & $\begin{array}{l}\text { Okul Öncesi } \\
\text { ÖA }\end{array}$ & 289 & 12.00 & 40.00 & 33.98 & 40.00 & 5.080 \\
\hline & Sinıf ÖA & 230 & 20.00 & 45.00 & 37.16 & 45.00 & 6.113 \\
\hline \multirow{2}{*}{$\begin{array}{l}\text { Öğrenme } \\
\text { arzunuz/hevesiniz }\end{array}$} & $\begin{array}{l}\text { Okul Öncesi } \\
\text { ÖA }\end{array}$ & 289 & 9.00 & 45.00 & 39.83 & 45.00 & 5.377 \\
\hline & Sinıf ÖA & 230 & 9.00 & 45.00 & 37.74 & 45.00 & 5.945 \\
\hline \multirow{2}{*}{$\begin{array}{l}\text { Mesleki alanıniza } \\
\text { ya da konu alanına } \\
\text { ilginiz }\end{array}$} & $\begin{array}{l}\text { Okul Öncesi } \\
\text { ÖA }\end{array}$ & 289 & 14.00 & 45.00 & 39.21 & 45.00 & 5.359 \\
\hline & Sinıf ÖA & 230 & 19.00 & 45.00 & 38.08 & 45.00 & 5.798 \\
\hline
\end{tabular}

Tablo 4 incelendiğinde okul öncesi öğretmen adayları ile sınıf öğretmeni adaylarının informal öğrenme etkinliklerinde bulunmalarını etkileyen kişisel özelliklerin toplam puanlarının ortalamalarına bakıldığında ise okul öncesi öğretmen adayları en fazla "Öğrenme arzusu/hevesi" ( $\bar{x}=39.83)$, boyutunun etkili olduğunu belirtirken, sinıf öğretmeni

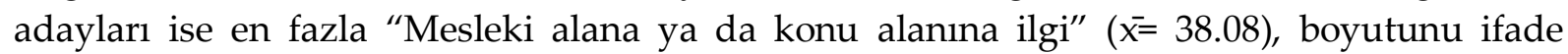
etmişlerdir. Diğer etki eden kişisel özelliklere bakıldığında okul öncesi öğretmen adayları

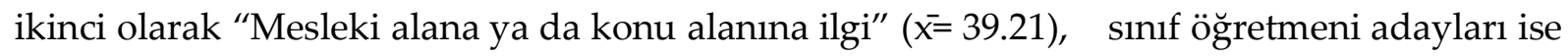

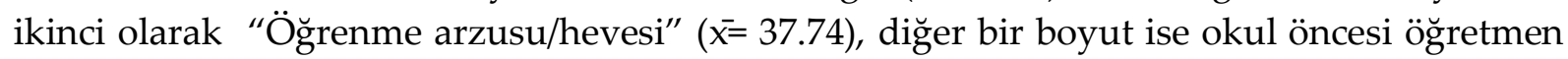
adayları ile sınıf öğretmeni adayları "Bir etkinliğe başlama ve devam etme kararlılığı" (oöa, $\bar{x}=37.27$, söa, $\bar{x}=37.20$ ), ve son olarak "Mesleki becerilere/yeteneklere ilişkin alg1" (oöa, $\overline{x=}$

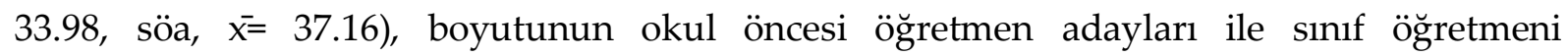
adaylarının informal öğrenme etkinliklerinde bulunmalarını etkilediği görülmüştür.

\section{Tartışma, Sonuç ve Öneriler}

Okul öncesi öğretmen adayları ile sınıf öğretmeni adaylarının informal öğrenme etkinliklerinin belirlenmesi için yapılan bu çalışmanın bulgularına bağlı olarak ortaya çıkan sonuçlar alan yazınında yapılmış diğer çalışmalar ile ilişkilendirilerek aşağıda sunulmuştur.

Okul öncesi öğretmen adayları ile sınıf öğretmeni adaylarının okul dışı gerçekleştirdikleri informal öğrenme etkinliklerinde en sık başvurdukları informal öğrenme etkinliği "İnternette arama yaparım" olduğu görülmektedir. En az başvurdukları informal öğrenme etkinliğinin ise "Mesleğimle/Alanımla ilgili dergileri incelerim" olduğu belirlenmiştir. Alan yazını incelendiğinde de benzer sonuçlara ulaşan araştırmalar olduğu görülmüştür. Lohman (2006) öğretmenlerin informal öğrenme faaliyetlerini incelediği araştırmasında öğretmenlerin en fazla diğer arkadaşları ile konuşmayı tercih ettikleri en az ise alanı ile ilgili kaynak tarama yaptıkları sonucuna ulaşmışlardır. Berg \& Chyung, (2008) iş yerlerinde kullanılan informal öğrenme etkinliklerini inceledikleri araştırmada, katılımcıların en çok başvurdukları yollardan birisinin kendi aralarında konuşmalar olduğunu tespit etmişlerdir. 
Alakurt (2015) bilişim teknolojileri öğretmenlerinin iş ortamlarındaki informal öğrenme davranışları belirleme amacı ile yaptığı çalışmada da öğretmenlerin en sık başvurdukları informal öğrenme etkinliğinin internette arama yapmak olduğu sonucuna ulaşmıştır. Ancak bilişim teknolojileri öğretmenleri az başvurdukları informal öğrenme etkinliğini Diğerlerini gözlemlerim şeklinde ifade ederken okul öncesi ve sinıf öğretmen adayları Mesleğimle/Alanımla ilgili dergileri incelerim ifadesi kullanmışlardır. Bu farklılığın sebebi olarak öğretmen adaylarının halen devam eden eğitimlerinin olduğu, teorik bilgileri okulda alıyor oluşları ile öğretmenlerin güncel durumları alanları ile ilgili dergilerden takip etmeleri olduğu düşünülmektedir.

Okul öncesi öğretmen adayları ile sınıf öğretmeni adaylarının informal öğrenme etkinliklerinde bulunmalarını etkileyen çevresel engelleyicilere bakıldığında en fazla "Zaman eksikliği/Zamanınınız olmama" çevresel engelleyicilerini ifade ederken, en az etkileyen çevresel engelleyicilere ise "Parasal ödüllerin olmama"sını ifade etmişlerdir. Bu sonuçlar Lohman (2006) ve Alakurt (2015) yaptığıkları araştırmaların sonuçları ile örtüşmektedir. Benzer bir çalışmada Karademir (2013), öğretmen ve öğretmen adaylarının okul dışı öğrenmeleri ile ilgili yaptığı araştırmada öğretmenlerin okul dışı etkinlik oluşturma durumlarının zaman ve maliyet bakımından farklılık gösterdiği öğretmenlerin okul dişı öğrenme ortamı etkinliklerini planlamada isteksiz olduklarını belirtmişlerdir. Aynı durum öğretmen adayları içinde geçerlidir nitekim öğretmen adayları da informal öğrenmelerinin önünde en büyük çevresel engelin zamanlarının olmayışını ifade etmişlerdir.

Okul öncesi öğretmen adayları ile sınıf öğretmeni adaylarının informal öğrenme etkinliklerinde bulunmalarını etkileyen kişisel özelliklerine bakıldığında okul öncesi öğretmen adayları en fazla "Öğrenme arzusu/hevesi" boyutunun etkili olduğunu belirtirken, sınıf öğretmeni adayları ise en fazla "Mesleki alana ya da konu alanına ilgi" boyutunu ifade etmişlerdir. En az etki eden kişisel özellik olarak da "Mesleki becerilere/yeteneklere ilişkin algı"larını ifade etmişlerdir. Benzer sonuçlar Lohman (2006) ve Alakurt (2015) yaptığıkları araştırmalarda da görülmektedir.

Araştırmanın sonuçlarına genel olarak bakıldığında; her iki anabilim dalına devam eden öğretmen adaylarının informal öğrenme yollarını etkili şekilde kullandıkları ve teknolojiyi informal öğrenme için hayata geçirdikleri görülmektedir. Öğretmen adaylarının informal öğrenme önünde en büyük çevresel engeli zaman sıkıntısı olarak ifade ettikleri belirlenirken informal öğrenmede en etkili kişisel özelliklerinin ise mesleklerine, alanlarına olan ilgileri ve öğrenme arzularının olduğu görülmüştür.

Araştırma sonuçlarına göre bazı öneriler sunulmaktadır. Bunlar; araştırma sonucunda öğretmenlerin en fazla interneti kullandıkları görülmüş nitel araştırmalarla internette ne aradıkları daha ayrıntılı şekilde ortaya konulabilir. Başka değişkenler ele alınarak informal öğrenmelere etkileri incelenebilir. Yaşam boyu öğrenme kapsamında informal öğrenme yolları ile ilgili öğretmenler bilgilendirilebilir. Öğretmenlerin alanları ile ilgili yayınlara ilişkin farkındalıkları artırılabilir bu yayınlara ulaşılabilirlikleri kolaylaştırıla bilinir. Okul dışı öğrenme uygulamaları ile ilgili okul öncesi ve sınıf öğretmenleri ile birlikte etkinlikler planlanarak uygulamalar yapıla bilinir.

\section{Teşekkür ve Bilgilendirme}

Bu çalışma, 21-24 Mart 2019 tarihinde Afyonkarahisar ilinde düzenlenen Uluslararası Bilim ve Eğitim Kongresinde (UBEK2019) sözlü bildiri olarak sunulmuştur. 


\section{Kaynakça}

Alakurt, T. (2015). Bilişim Teknolojileri Öğretmenlerinin İş Ortamlarındaki İnformal Öğrenme Davranışları. İlköğretim Online, 14(3), 934-945.

Alakurt, T , Öztürk, H , Karademir, T , Yılmaz, B . (2019). Mesleki Gelişim Bağlamında Bilişim Teknolojileri Öğretmenlerinin Öğrenme Durumlarının İncelenmesi. Eğitim Teknolojisi Kuram ve Uygulama , 9 (1) , 127-153 . DOI: 10.17943/etku.435031

Berg, S. A., \& Chyung, S. (2008). Factors that influence informal learning in the workplace. Journal of Workplace Learning, 20(4), 229-244

Bozdoğan, A. E. (2007). Students interests towards science fields about exhibitions in science centers: Feza Gursey Science Center in Turkey. Natural Science Education. 2 (19), 5-17.

Eraut, M. (2004). Informal learning in the workplace. Studies in Continuing Education, 26, 247-273. doi:https://doi.org/10.1080/158037042000225245

Garrick, J. (2001). Informal learning in the workplace: Unmasking human resource development. London: Routledge.

Göğebakan Yıldız, D. (2017). Yaşam boyu öğrenme. S. Z. Genç (Ed.), Değiş̧en değerler ve yeni eğitim paradigması (s.198-224). Pegem Akademi, Ankara.

Güleç, İ., Çelik, S. ve Demirhan B. (2012). Yaşam Boyu Öğrenme Nedir? Kavram ve Kapsamı Üzerine Bir Değerlendirme. Sakarya University Journal of Education, 2/3 3448.

Hofstein, A. \& Rosenfeld, S. (1996). Bridging the gap between formal and informal science learning. Studies in Science Education, 28, 87-112.

Kara, E. (2010). Fen ve teknoloji eğitiminde informal bilimsel liderlik. (Yüksek lisans tezi. Erzincan Universitesi, Erzincan). http://tez2.yok.gov.tr/

Karademir, E. (2013). Öğretmen ve öğretmen adaylarının fen ve teknoloji dersi kapsamında okul dışı öğrenme etkinliklerini gerçekleştirme amaçlarının planlanmış davranış teorisi yoluyla belirlenmesi.(Doktora tezi, Hacettepe Üniversitesi, Ankara). http://tez2.yok.gov.tr/

Karasar, N. (2012). Bilimsel Araştırma Yöntemi (25. Bask). Ankara: Nobel Yayıncılık

Kaya, H.E (2016). Yaşam boyu yetişkin eğitimi. Ankara: Nobel Akademi Yayıncılık.

Keskin, S.ve Kaplan, E.(2012). Sosyal bilgler ve tarih eğitiminde okul dışı öğrenme ortamı olarak oyuncak müzeleri, Elektronik Sosyal Bilimler Dergisi, 41, 95-115.

Lakin. L. (2006). Science beyond the classroom. Journal of Biological Education. 40:2. 89-90.

Livingstone, D. (2002). Mapping the iceberg. NALL Working Paper\#54.[Online]http://nall.oise.utoronto.ca/res/54DavidLivingstone.pdf 2013

Lohman, M. C. (2005). A survey of factors influencing the engagement of two professional groups in informal workplace learning activities. Human Resource Development Quarterly, 16(4), 501-527. 
Lohman, M.C. (2006). Factors influencing teachers' engagement in informal learning activities, Journal of Workplace Learning, Vol. 18 No. 3, pp. 141-56.

Melber, L.M. \& Brown K.D. (2008). "Not like a regular science class": Informal science education for students with disabilities. A Journal of Educational Strategies 82(1), 3539 .

Moore, A.L., Klein, J.D. (2020). Facilitating Informal Learning at Work. TechTrends 64, 219228. https://doi.org/10.1007/s11528-019-00458-3

Rogers, A. 2013. The Classroom and the Everyday: The Importance of Informal Learning for Formal Learning. Investigar Em Educacao 1(1), 2014, 7-34.

Stocklmayer, S.M., Rennie, L.J., \& Gilbert, J.K. (2010). The roles of the formal and informal sectors in the provision of effective science education. Studies in Science Education, $46(1), 1-44$.

Türkmen, H. (2010). İnformal (Sınıf-Dışı) Fen bilgisi eğitimine tarihsel bakış ve eğitimimize entegrasyonu. Çukurova Üniversitesi Ĕ̆itim Fakültesi Dergisi, 3 (39), 4659 .

Wulf, R., Mayhew, L. \& Finkelstein, D.(2010). Impact of informal science education on children's attitudes about science. Physics Education Research Conference 1289, 337340 .

Yavuz, M. ve Balkan Kıyıcı, F. (2012). İnformal öğrenme ortamlarının ilköğretim öğrencilerinin fene karşı kaygı düzeylerinin değişmesine ve akademik başarılarına etkisi: Hayvanat bahçesi örneği. X. Ulusal Fen Bilimleri ve Matematik Ĕ̆itimi Kongresi. Niğde Üniversitesi Eğitim Fakültesi, Niğde. 